University of Nebraska - Lincoln

DigitalCommons@University of Nebraska - Lincoln

USDA National Wildlife Research Center - Staff Publications
U.S. Department of Agriculture: Animal and Plant Health Inspection Service

2017

\title{
Greater Sage-Grouse Nest Survival in Northwestern Wyoming
}

Jimmy D. Taylor II

USDA/APHIS/WS National Wildlife Research Center, jimmy.d.taylor@usda.gov

R. Douglas Holt

Oregon State University

Elizabeth K. Orning

Utah State University

Julie K. Young

USDA/APHIS/WS National Wildlife Research Center, julie.k.young@aphis.usda.gov

Follow this and additional works at: https://digitalcommons.unl.edu/icwdm_usdanwrc

Part of the Life Sciences Commons

Taylor, Jimmy D. II; Holt, R. Douglas; Orning, Elizabeth K.; and Young, Julie K., "Greater Sage-Grouse Nest Survival in Northwestern Wyoming" (2017). USDA National Wildlife Research Center - Staff Publications. 1969.

https://digitalcommons.unl.edu/icwdm_usdanwrc/1969

This Article is brought to you for free and open access by the U.S. Department of Agriculture: Animal and Plant Health Inspection Service at DigitalCommons@University of Nebraska - Lincoln. It has been accepted for inclusion in USDA National Wildlife Research Center - Staff Publications by an authorized administrator of DigitalCommons@University of Nebraska - Lincoln. 


\title{
Greater Sage-Grouse Nest Survival in Northwestern Wyoming
}

\author{
JIMMY D. TAYLOR, ${ }^{\mathbf{1}}$ USDA, APHIS, National Wildlife Research Center, Oregon Field Station, 321 Richardson Hall, Corvallis, OR 97331, USA \\ R. DOUGLAS HOLT, ${ }^{2}$ Forest Ecosystems and Society Department, Oregon State University, 321 Richardson Hall, Corvallis, OR 97331, USA \\ ELIZABETH K. ORNING, ${ }^{3}$ Department of Wildland Resources, Utah State University, Logan, UT 84322, USA \\ JULIE K. YOUNG, USDA, APHIS, National Wildlife Research Center, Predator Research Facility, Department of Wildland Resources, Logan, UT \\ 84322-5295, USA
}

\begin{abstract}
Nest survival, along with female survival and chick survival, is the most important vital rates to population growth of greater sage-grouse (Centrocercus urophasianus; sage-grouse). We used global positioning system and very high-frequency transmitters on female sage-grouse to identify 204 nests and monitor incubation on 5 sites in the Bighorn Basin, Wyoming from 2011 to 2014; we determined nest fate and identified predators with camera traps. We used an information-theoretic approach to compare 6 a priori nest survival models. Nest survival was best described by a model that included differences across study sites and ranged from $0.20 \pm 0.01$ (SE) to $0.56 \pm 0.05$. Coyotes (Canis latrans) were the apex predator, and coyotes were removed annually by United States Department of Agriculture, Animal and Plant Inspection Service, Wildlife Services on 4 of 5 sites to reduce depredation to livestock and big game ( $\bar{x}$ removal $=0-0.56$ coyotes $\left./ \mathrm{km}^{2} / \mathrm{site}\right)$. Coyotes were the greatest contributor to nest failure, followed by common ravens (Corvus corax), abandonment, and female mortality. The direct effect of nest depredation by coyotes was greater than other reported sage-grouse studies, yet our nest survival rates were consistent with others reported throughout the species range. Coyote removal did not appear to have indirect effects, such as a mesopredator release, on nest survival. Nest survival was least on a site where coyotes and ravens depredated nests at nearly the same rate, and where ravens were observed nesting on infrastructure close to nesting sage-grouse. (C) 2017 The Wildlife Society.
\end{abstract}

KEY WORDS Bighorn Basin, cameras, common raven, coyote, greater sage-grouse, mesopredator release, nest success, wildlife damage management.

Greater sage-grouse (Centrocercus urophasianus; sage-grouse) populations have declined and presently occupy approximately $56 \%$ of their range that existed prior to human settlement of the Great Plains (Connelly and Braun 1997, Schroeder et al. 2004). The current range includes portions of 11 western states and 2 Canadian provinces (Schroeder et al. 2004); however, individual populations have become increasingly geographically isolated (Knick et al. 2003). The causes of this decline have been attributed to the loss and fragmentation of native sagebrush (Artemisia spp.) rangeland (Knick et al. 2003) from conversion of native rangeland for agricultural purposes (Braun 1998), altered fire regimes, mineral exploration and extraction (Noss et al. 1995), poor grazing practices (Connelly et al. 2000), and invasion of

Received: 26 September 2016; Accepted: 14 May 2017

\footnotetext{
${ }^{1}$ Email: jimmy.d.taylor@aphis.usda.gov

${ }^{2}$ Present Address: Togiak National Wildlife Refuge, P.O. Box 270, Dillingham, AK 99576, USA.

${ }^{3}$ Present Address: Oregon Cooperative Fish and Wildlife Research Unit, Department of Fisheries and Wildlife, Oregon State University, Corvallis, OR 97331, USA.
}

exotic and invasive grass species (Miller et al. 2011). Despite decades of research, little is known about the habitatpredator interactions associated with sage-grouse demographics (Hagen 2011, Conover and Roberts 2017).

The United States Fish and Wildlife Service (USFWS) received petitions to list sage-grouse as threatened or endangered across the entire range in accordance with section 4 of the Endangered Species Act of 1973 (ESA), as amended (16 U.S.C. 1531 et seq.), and announced a not-warranted 12-month finding in 2005 (USFWS 2010). Listing of sagegrouse was subsequently determined to be warranted but precluded by higher priority listing actions in 2010 (USFWS 2010). More recently USFWS released another finding of not warranted (USFWS 2015). The most recent decision was based on conservation measures implemented by local and state agencies such as the Wyoming Game and Fish Department (WGFD). However, conservation of the species still remains a concern and efforts to broaden understanding of life-history and demographic parameters are desired.

Approximately $37 \%$ of the current occupied sage-grouse range occurs within the state boundary of Wyoming, representing $64 \%$ of the eastern population of sage-grouse (Doherty et al. 2011). Recognizing this distribution, sage-grouse in Wyoming 
are predicted to remain a stronghold for the population at large (Knick et al.2003). Understanding regional-specific population parameters would improve development of relevant management activities. Yet, reports of vital rates from across sage-grouse range vary (Taylor et al. 2012), accentuating the importance of understanding local population dynamics and conducting multi-year studies.

Low recruitment, determined by nest and chick survival, is a limiting factor in sage-grouse population growth (Crawford and Lutz 1985, Gregg et al. 1994, Taylor et al. 2012). As such, nest survival is a key demographic parameter to consider for the conservation of sage-grouse populations (Gregg et al. 1994, Schroeder and Baydack 2001). The leading cause of sage-grouse nest failure is nest loss to predators (Moynahan et al. 2007, Coates and Delehanty 2010, Webb et al. 2012). The composition of the predator community could influence the magnitude of nest failure on local avian populations (Evans 2004).

Management strategies that strive to improve nest survival generally focus on improving nesting habitat and rarely account for predator dynamics. Management decisions (i.e., managing for species composition, height, juxtaposition) are based on assumptions about how females assess habitat conditions, although nest site selection and nest survival may be influenced by factors other than vegetation characteristics immediately surrounding nests (Holloran et al. 2005). Additionally, nest fate may be influenced by biotic factors outside of a nesting female's control. For example, Dinkins et al. (2012) showed that females select nest sites away from avian predators, whereas other studies have shown that daily survival rates of nests decrease 1 day after rain events (Moynahan et al. 2007, Webb et al. 2012), possibly because of increased detection by olfactory predators (Conover et al. 2010). Sage-grouse management generally does not include predator management; however, predators in proximity to sage-grouse are often managed for other reasons (e.g., protecting livestock and big game during birthing and rearing periods; Conover and Roberts 2017, Dinkins et al. 2016).

We conducted an observational study to examine factors influencing sage-grouse nest survival in northwestern Wyoming in the presence of ongoing lethal predator control for other purposes. We sought to characterize the suite of predators visiting sage-grouse nests and expand upon the photo and video evidence documented by others (Holloran and Anderson 2003, Coates et al. 2008, Coates and Delahanty 2010, Lockyer et al. 2013). We expected to see a greater frequency of coyotes (Canis latrans) at nests than previously recorded (Lockyer et al. 2013). We also expected that sage-grouse nest survival would be least, and nest loss to coyotes would be greatest, where coyotes were not managed for livestock and big game protection.

\section{STUDY AREA}

We examined sage-grouse nest survival at 5 sites during sage-grouse nesting season (Apr-Jul 2011-2014) throughout the Bighorn Basin, Wyoming, which occurs within the Wyoming Basin ecoregion (Chapman et al. 2004, Omernich and Griffith 2012). The area was intermountain and included Bighorn, Hot Springs, Park, and Washakie counties in Wyoming. The broad area typically referred to as Bighorn Basin is $32,000 \mathrm{~km}^{2}$ and our study sites represented $1,094 \mathrm{~km}^{2}$ : 1 site in Hot Springs County (Major Basin $=257 \mathrm{~km}^{2}$ ), 3 sites in Park County (Fifteen Mile $=262 \mathrm{~km}^{2}$, Oregon Basin $=130 \mathrm{~km}^{2}$, and Polecat Bench $=341 \mathrm{~km}^{2}$ ), and 1 site in Washakie County $\left(\right.$ Bud Kimball $\left.=104 \mathrm{~km}^{2}\right)$. Elevation at the sites ranged from $1,230 \mathrm{~m}$ to $1,750 \mathrm{~m}$ above sea level. Average monthly temperatures between March and August $2011-2014$ ranged from $3.0^{\circ} \mathrm{C}$ in March to $22.6^{\circ} \mathrm{C}$ in July (Western Regional Climate Center 2016). Average monthly rainfall between March and August 2011-2014 ranged from $0.5 \mathrm{~cm}$ in August to $6.3 \mathrm{~cm}$ in May (Western Regional Climate Center 2016).

Vegetation communities consisted of shrubs dominated by Wyoming big sagebrush (Artemisia tridenta wyomingensis) and also included bud sagebrush (Picrothamnus desertorum), low sagebrush ( $A$. arbuscula), birdfoot sagebrush ( $A$. pedatifida), basin big sagebrush (A. t. tridenta), greasewood (Sarcobatus vermiculatus), shadscale saltbush (Atriplex confertifolia), fourwing saltbush (A. canescens), and Gardner's saltbush (A. gardneri; Knight 1994, Winward 2004, WGFD 2010). Cool-season grasses included Indian ricegrass (Achnatherum hymenoides), squirreltail (Elymus elymoides), western wheatgrass (Pascopyrum smithii), and Sandberg bluegrass (Poa secunda; WGFD 2010). Warm-season grasses included alkali sacaton (Sporobolis airoides), sand dropseed (S. cryptandrus), and blue grama (Bouteloua gracilis; Blaisdell and Holmgren 1984). Forbs included Hooker's sandwort (Arenaria hookeri) spiny phlox (Phlox hoodii), and globemallow (Sphaeralcea spp.; WGFD 2010). Invasive species included Japanese brome (Bromus japonicus), cheatgrass (B. tectorum), Canada thistle (Cirsium arvense), hoary cress (Cardaria draba), knapweed (Centaurea spp.), and toadflax (Linaria spp.; Knight 1994, Hess and Beck 2012).

The predominant land-use was livestock grazing by sheep and cattle. Additional land-uses included oil and natural gas exploration and extraction and bentonite mining (Omernick and Griffith 2012). The ecoregion contains the Bighorn, Shoshone, and Greybull rivers, which provided water for irrigated crop cultivation (Omernich and Griffith 2012). Active predator control was ongoing to protect livestock and big game species throughout the study area. Protection of big game was primarily for mule deer (Odocoileus hemionus) and pronghorn (Antilocapra americana), although elk (Cervus elaphus) also used the study area. Predator control was coordinated through Predator Management Districts in Wyoming and performed by United States Department of Agriculture, Animal and Plant Inspection Service, Wildlife Services (USDA/APHIS/WS). Although coyotes were the primary predator species removed for livestock and big game protection, other species were removed to protect livestock. They included common raven (Corvus corax; ravens), feral cat, raccoon (Procyon lotor), porcupine (Erethizon dorsatum), red fox (Vulpes vulpes), and striped skunk (Mephitus mephitus). Prior to initiating the study, we coordinated to set aside 1 site (Oregon Basin) where no predators were 
removed from 2011-2014. Other common species in Bighorn Basin that we considered potential predators of attending females or nests included American badger (Taxidea taxus; badgers), bobcat (Felis rufus), long-tailed weasel (Mustela frenata), gopher snake (Pituophis catenifer), black-billed magpie (Pica budsonia), and golden eagle (Aquila chrysaetos).

\section{METHODS}

We defined study site boundaries and associated area (ha) post hoc in a geographic information system by buffering a fixed distance around all known leks and known nest sites. We obtained numbers of coyotes removed for big game and livestock protection for 2011-2014 by study site (USDA/ APHIS/WS, unpublished data). We also accounted for the additional removal of coyotes by Wildlife Services on Polecat Bench from 14 March-15 June 2012 (Orning 2014). We calculated mean removal and standard error per $\mathrm{km}^{2}$ for each site using Program R (R Core Team 2013). We reported mean removal $/ \mathrm{km}^{2} /$ site for 2011-2014 regardless of the year a site entered the study.

We captured female sage-grouse with rocket nets on leks in spring each year (Schemnitz 1994). We captured additional females with spotlights and hoop nets during autumn 2011 (Connelly et al. 2003). We removed females from nets and placed them in cloth bags for holding until processing. We classified females as juvenile (first breeding season post-hatch) or adult (after first breeding season posthatch) based on the shape and condition of outer primary feathers (Crunden 1963). We fitted females with either a very high frequency (VHF) necklace-style radio-transmitter equipped with a 12-hour mortality sensing switch or a backpack-style global positioning system (GPS) transmitter, and released them at the capture site. All transmitters were $<3 \%$ of female sage-grouse body weight. All study methods were approved by the Institutional Animal Use and Care Committee of the USDA/APHIS/WS/National Wildlife Research Center (Protocol QA-1860), and the Wyoming Game and Fish Department (Chapter 33 Permits No. 802 and 892).

We monitored birds with VHF transmitters $\geq 3$ days/week during the nesting season. We located individuals using the homing technique to within 100-200 m or tracked from the air using fixed-wing aircraft (Samuel and Fuller 1994). We received location data for birds marked with GPS transmitters from ARGOS satellites every 3 days. When we estimated a bird marked with a VHF transmitter to be stationary for $\geq 3$ locations without receiving a mortality signal, we assumed the bird was incubating a nest and verified this with a site visit. If GPS-marked birds were stationary for $\geq 3$ days we inspected the site to determine if a nest was present.

Accurate assignment of specific causes of nest failure can be difficult because of scavenging (Coates et al. 2008); therefore, we placed motion sensing cameras at nests to accurately determine the predator species if the nest failed (Cox et al. 2012). We followed applicable recommendations by Richardson et al. (2009) to minimize potential camera bias. For example, we minimized visual conspicuousness by camouflaging cameras within live vegetation, lessened olfactory conspicuousness by walking in and out the same path for camera placement and minimizing time on station, minimized changes to nest concealment by focusing cameras on nest bowls but away from the nest, and avoided long-term persistent use of cameras by removing individual cameras as soon as we determined nest fate. Additionally, we used fresh batteries and empty, high-capacity memory cards with each camera deployment to ensure repeated visits were not required during incubation.

We monitored incubation by birds equipped with VHF transmitters by checking signal direction and intensity from a marked location $>300 \mathrm{~m}$ from the nest site to avoid disturbance after the initial nest check. We classified nest fate based on field observations and retrieved the camera after we verified an incubating sage-grouse had left the nest. We classified nests as successful if we observed $\geq 1$ capped eggshell with detached membranes (Wallestad and Pyrah 1974). If the nest bowl was empty or we observed crushed eggshells, we classified the nest as a failure. When nests contained whole intact eggs that were cool to the touch, we classified the nest as abandoned. If we suspected nest abandonment, we returned to the nest monitoring location for 3 consecutive days to verify that the incubating female was not on a break to forage when we observed her away from the nest.

We reviewed images from camera memory cards to assess the dates incubating birds left their nests and to confirm or deny nest fate assessed by field observations. We classified nest predators based on photographic evidence and female behavior. When we observed predators at the location of the nest bowl and then observed that the female did not return to continue incubation of the nest, we assigned the cause of nest failure to the specific predator observed. If we could not identify specific predators from photographic evidence and there were other indications of nest failure (i.e., $\mathrm{F}$ did not return to incubation and field observations), we assigned the cause of nest failure as unidentifiable.

We estimated the daily survival rate (DSR) of nests using the logit-link function for the nest model (Dinsmore et al. 2002, Rotella et al. 2004) in Program MARK (White and Burnham 1999). We converted DSR estimates to nest survival estimates and approximated nest survival variances using the delta method (Seber 1982, Powell 2007). We assumed an incubation period of 28 days (Johnson 1979, Schroeder et al. 1999) when transforming daily nest survival rates to nest survival rates. We developed 6 a priori models to describe nest survival of marked sage-grouse (Table 1). We used information theoretic criteria based on Akaike's Information Criterion (Akaike 1973, Burnham and Anderson 1998) corrected for small sample size (AIC ${ }_{c}$; Anderson et al. 2000) to determine which of our a priori models best described nest survival of marked sage-grouse from 2011-2014. We used the evidence ratio of Akaike weights among models and the number of units $\Delta \mathrm{AIC}_{c}$ between models to determine the strength of the best parsimonious model. 
Table 1. Description of a priori models used to describe nest survival $(S)$ of marked sage-grouse across the Bighorn Basin, Wyoming, USA, 2011-2014.

\begin{tabular}{ll}
\hline Model & Description \\
\hline$S_{\text {intercept only }}$ & No difference in nest survival due to study \\
& site, year, or seasonal trend. \\
$S_{\text {site }}$ & Nest survival differs by site. \\
$S_{\text {year }}$ & Nest survival differs by year. \\
$S_{\text {year } \times \text { site }}$ & Nest survival differs by site and year \\
$S_{\text {within year linear trend }}$ & interaction. \\
& Nest survival varies linearly within year and \\
$S_{\text {within year quadratic trend }}$ & does not differ across years. \\
& Nest survival varies quadratically within year \\
& and does not differ across years. \\
\hline
\end{tabular}

\section{RESULTS}

No predators were taken by Wildlife Services at Oregon Basin during this study. Mean number of coyotes removed/ $\mathrm{km}^{2}$ for livestock or big game protection were similar between Bud Kimball, Fifteen Mile, and Major Basin (Table 2). Mean number of coyotes removed $/ \mathrm{km}^{2}$ at Polecat Bench were least among all removal sites from 2011-2014, including the additional coyotes removed for an experiment (Orning 2014) to evaluate effects on sage-grouse in spring 2012 (Table 2). A small number of ravens were removed from Major Basin in 2012 and 2014 to protect young livestock (Fig. 1). Other predators that were removed to protect agriculture and livestock included feral cat, raccoon, porcupine, red fox, and striped skunk. Removal of others were relatively low compared to coyotes on all sites except Polecat Bench, where raccoons were the most frequently removed predator (Fig. 1).

We radio-marked female sage-grouse on Polecat Bench $(n=51)$ and Oregon Basin $(n=63)$ from 2011 to 2014, Major Basin $(n=48)$ and Fifteen Mile $(n=47)$ from 2012 to 2014, and Bud Kimball $(n=16)$ in 2014. We monitored 204 sage-grouse nests during the study (Table 3). We standardized nesting season days across years by setting the earliest date that we located a nest (8 Apr 2012) as day 1 and the last day we monitored an active nest ( 8 Jul 2011) as day 91 resulting in 90 daily intervals for which we could estimate daily nest survival. We observed 19 re-nest attempts (2 in 2011,1 in 2012, 5 in 2013, 11 in 2014) representing 9\% of the overall nest attempts we observed. Because of the small sample size of re-nest attempts with respect to overall nest attempts, we did not include nest attempt as a covariate in our models (Kirol et al. 2015). As such, we implicitly

Table 2. Mean (SE) number of coyotes removed per $\mathrm{km}^{2}$ by United States Department of Agriculture, Animal and Plant Health Inspection Service, Wildlife Services for livestock and big game protection across 5 study sites in Bighorn Basin, Wyoming, USA, 2011-2014.

\begin{tabular}{lcc}
\hline Study site & $\overline{\boldsymbol{x}}$ coyote removal $/ \mathbf{k m}^{\mathbf{2}}$ & SE \\
\hline Bud Kimball & 0.51 & 0.09 \\
Fifteen Mile & 0.42 & 0.05 \\
Major Basin & 0.56 & 0.06 \\
Oregon Basin & 0.00 & \\
Polecat Bench & 0.19 & 0.03 \\
\hline
\end{tabular}

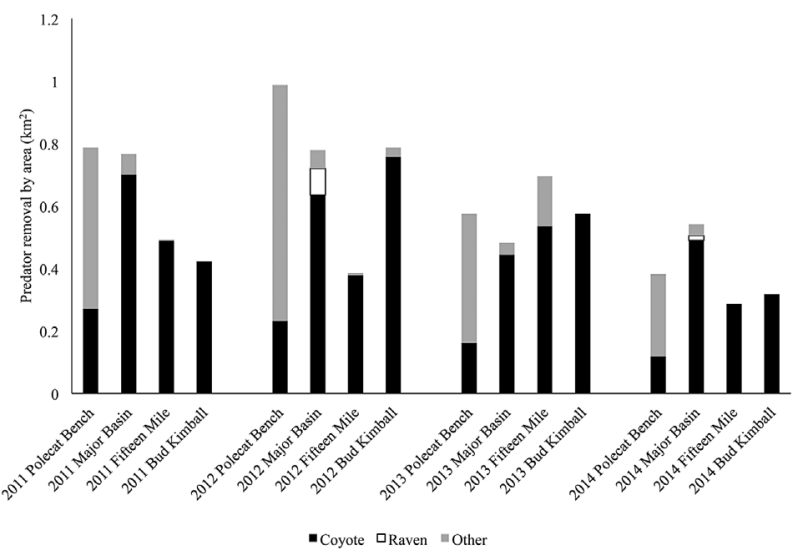

Figure 1. Numbers of predators removed per $\mathrm{km}^{2}$ per year by United States Department of Agriculture, Animal and Plant Health Inspection Service, Wildlife Services for livestock and big game protection across 4 managed study sites in Bighorn Basin, Wyoming, USA, 2011-2014.

assumed that survival functions were similar for first nest attempts and re-nest attempts.

Nest survival was best described by a model that included differences across study sites (Table 4). The top model differed from the next closest model by $>7 \Delta \mathrm{AIC}_{c}$ and had $96 \%$ of the $\mathrm{AIC}_{c}$ weight. Site-specific nest survival estimates were $0.56 \pm 0.05$ (SE) for Fifteen Mile, $0.45 \pm 0.03$ for Oregon Basin, $0.35 \pm 0.05$ for Bud Kimball, $0.33 \pm 0.03$ for Major Basin, and $0.20 \pm 0.01$ for Polecat Bench.

Coyotes were the greatest contributor to nest failure in this study (Table 5). Other causes of nest failure included abandonment, female mortality, and nest depredation by raven, badger, red fox, striped skunk, gopher snake, and pronghorn. The greatest cause of nest failure for the Bud Kimball site was abandonment (Table 5). The greatest cause of nest failure for the Major Basin site was depredation by badgers, which were classified as other causes of nest failure because of the low proportion of badger nest depredation events observed at other sites (Table 5). We observed badger depredation of sage-grouse nests only at one other site (Polecat Bench) over the duration of the study. The greatest cause of nest failure for Fifteen Mile, Oregon Basin, and Polecat Bench was depredation by coyotes (Table 5). Where nest survival was lowest (Polecat Bench), we observed a disproportionate failure of nests from depredation by ravens relative to the other study sites. The proportion of sagegrouse nests lost on Polecat Bench to ravens was almost equal to coyotes, a stark contrast to all other sites (Table 5).

\section{DISCUSSION}

Predator control is a management tool (Leopold 1933, Reynolds and Tapper 1996, Treves and Naughton-Treves 2005) that is often controversial. With few exceptions, predator management for sage-grouse conservation is not prescribed in North America (Schroeder and Baydack 2001, Hagen 2011). Rather, predator management has been couched within improving habitat quality for sage-grouse (Schroeder and Baydack 2001, Holloran et al. 2005). Vegetation characteristics at nests were not different between 
Table 3. Number of sage-grouse nests (including no. renest attempts in parentheses) monitored for nest survival at 5 sites in Bighorn Basin, Wyoming, USA, 2011-2014.

\begin{tabular}{|c|c|c|c|c|c|c|c|c|c|c|c|c|}
\hline \multirow{2}{*}{$\begin{array}{l}\mathbf{Y r} \\
2011\end{array}$} & \multicolumn{2}{|c|}{$\begin{array}{c}\text { Oregon } \\
\text { Basin }\end{array}$} & \multicolumn{2}{|c|}{$\begin{array}{c}\text { Polecat } \\
\text { Bench }\end{array}$} & \multicolumn{2}{|c|}{$\begin{array}{c}\text { Fifteen } \\
\text { Mile }\end{array}$} & \multicolumn{2}{|c|}{$\begin{array}{c}\text { Major } \\
\text { Basin }\end{array}$} & \multicolumn{2}{|c|}{$\begin{array}{c}\text { Bud } \\
\text { Kimball }\end{array}$} & \multicolumn{2}{|c|}{ Total } \\
\hline & 13 & (1) & 8 & (1) & & & & & & & 21 & (2) \\
\hline 2012 & 8 & (0) & 14 & (1) & 10 & $(0)$ & 6 & $(0)$ & & & 38 & (1) \\
\hline 2013 & 17 & (0) & 18 & (1) & 16 & (1) & 15 & (3) & & & 66 & (5) \\
\hline 2014 & 22 & (5) & 22 & (4) & 14 & (1) & 11 & (0) & 10 & (1) & 79 & (11) \\
\hline Total & 60 & (6) & 62 & (7) & 40 & (2) & 32 & (3) & 10 & (1) & 204 & (19) \\
\hline
\end{tabular}

sites nor did they affect nest fate in the first years of this study (Orning 2014). Unfortunately, we were unable to continue collecting vegetation data in subsequent years because of logistical constraints. For this study, we assumed that nesting habitat was similar for all sites and years.

Although lethal predator control for sage-grouse is generally not recommended, predator management to protect livestock and big game species is socially accepted in the western United States. Where livestock, predators, and sage-grouse share areas of sagebrush, many of the interrelationships are unknown (Crawford et al. 2004). A key to understanding trophic interactions is to identify the predators and prey. Scent station surveys and avian counts in 2011-2012 confirmed that badger, black-billed magpie, bobcat, coyote, feral cat, long-tailed weasel, raccoon, raven, red fox, and striped skunk were present as potential nest predators (Orning 2014). Scent station surveys also confirmed the presence of 2 species of lagomorphs (blacktailed jackrabbit [Lepus spp.] and cottontail [Sylvilagus spp.]) as alternate prey items (Orning 2014). Of the likely nest predators, we documented nest depredation by badger $(n=8)$, coyote $(n=33)$, raven $(n=21)$, red fox $(n=1)$, and striped skunk $(n=1)$ with remote cameras. Ravens and badgers were previously recorded depredating sage-grouse nests by videography in northeastern Nevada (Coates et al. 2008) and northwestern Nevada (Lockyer et al. 2013). Holloran and Anderson (2003) also remotely photographed badgers destroying a sage-grouse nest in southeastern Wyoming.

To our knowledge, our study contains the largest dataset of known sage-grouse nest fates through remote imagery and is the first to document coyotes as the most frequent nest predator of sage-grouse nests, accounting for $27.7 \%$ of all failed nests and $50 \%$ of all nests destroyed by known predators. Previous studies have considered coyotes as predators of sage-grouse nests (Wallestad and Pyrah 1974, DeLong et al. 1995, Moynahan et al. 2007); however, little evidence existed prior to this study to positively document coyotes as sage-grouse nest predators. Conover and Roberts (2017) reviewed 105 depredated sage-grouse nests, from multiple studies, and reported more nests were destroyed by ravens and badgers than coyotes. Lockyer et al. (2013) identified coyotes as sage-grouse nest predators in northwestern Nevada using videography. However, ravens were the most frequent nest predator in that study, accounting for $46.7 \%$ of nest depredations (Lockyer et al. 2013). Bobcat and long-tailed weasel also were recorded depredating sagegrouse nests in northwestern Nevada (Lockyer et al. 2013). Although we observed bobcats and weasels in the field or documented their presence with track plate surveys (Orning 2014), we did not observe them at nest sites.

In Bighorn Basin, we found the coyote to be the apex predator in the sagebrush-dominated system. Across our 5 study sites, coyote densities were estimated to be greatest in sagebrush $\left(0.214\right.$ coyotes $\left./ \mathrm{km}^{2}\right)$ on Bureau of Land Management and private lands where coyote control occurred (E. M. Gese and P. A. Terletzky, Utah State University, unpublished report). Removal of predators in this study was done at the appropriate time and intensity to reduce impacts to protected resources; thus, predator control occurred during and outside of the sage-grouse nesting seasons. This is common for wildlife damage management activities such as those conducted by Wildlife Services. Although it would have been desirable to evaluate the potential effects of each removal on nearby nest survival, and the potential effects on trophic interactions in the predator guild, this was not possible.

Despite active coyote control, coyotes were the leading cause of sage-grouse nest failure on 2 of our 4 sites with removals (Fifteen Mile, Polecat Bench) and the site with no removals (Oregon Basin). Thus, these 3 sites represented the full range of mean coyote removal/unit area across the study (i.e., no removal to intermediate to most; Table 2). We expected removal sites to maintain a coyote density near

Table 4. Nest survival $(S)$ models for nests of marked sage-grouse on at 5 sites in Bighorn Basin, Wyoming, USA, 2011-2014. AIC $c$ represents Akaike's Information Criterion corrected for small sample size.

\begin{tabular}{|c|c|c|c|c|c|c|}
\hline Model & $\mathrm{AIC}_{c}$ & $\Delta \mathrm{AIC}_{c}$ & $\mathrm{AIC}_{c}$ weights & Model likelihood & No. parameters & Deviance \\
\hline$S_{\text {study site }}$ & 941.70 & 0.00 & 0.96 & 1.00 & 5 & 931.68 \\
\hline$S_{\text {study site } \times \text { year }}$ & 949.46 & 7.76 & 0.02 & 0.02 & 15 & 919.31 \\
\hline$S_{\text {intercept only }}$ & 951.11 & 9.42 & 0.01 & 0.01 & 1 & 949.11 \\
\hline$S_{\text {within year quadratic trend }}$ & 953.01 & 11.31 & $<0.01$ & $<0.01$ & 2 & 949.00 \\
\hline$S_{\text {within year linear trend }}$ & 953.06 & 11.37 & $<0.01$ & $<0.01$ & 2 & 949.06 \\
\hline$S_{\text {year }}$ & 953.60 & 11.90 & $<0.01$ & $<0.01$ & 4 & 945.58 \\
\hline
\end{tabular}


Table 5. Causes of nest failure of marked sage-grouse on 5 sites in Bighorn Basin, Wyoming, USA, 2011-2014 reported as a proportion of all nests located by site. We grouped causes of failure that were identifiable but had low frequency of occurrence as other. We grouped causes of failure that were questionable and could not be determined through trap camera images as unidentified.

\begin{tabular}{|c|c|c|c|c|c|c|c|c|c|c|c|c|c|c|}
\hline \multirow[b]{2}{*}{ Study site } & \multirow[b]{2}{*}{$\begin{array}{c}\text { No. nests } \\
\text { located }\end{array}$} & \multirow[b]{2}{*}{$\begin{array}{c}\text { No. failed } \\
\text { nests }\end{array}$} & \multicolumn{2}{|c|}{ Abandoned } & \multicolumn{2}{|c|}{ F mortality } & \multicolumn{2}{|r|}{ Raven } & \multicolumn{2}{|r|}{ Coyote } & \multicolumn{2}{|c|}{ Unidentified } & \multicolumn{2}{|r|}{ Other $^{a}$} \\
\hline & & & $n$ & Proportion & $n$ & Proportion & $n$ & Proportion & $n$ & Proportion & $n$ & Proportion & $n$ & Proportion \\
\hline Bud Kimball & 10 & 6 & 3 & 0.30 & 1 & 0.10 & 1 & 0.10 & 1 & 0.10 & 0 & & 0 & \\
\hline Fifteen Mile & 40 & 16 & 2 & 0.05 & 2 & 0.05 & 1 & 0.03 & 8 & 0.20 & 3 & 0.08 & 0 & \\
\hline Major Basin & 32 & 18 & 3 & 0.09 & 1 & 0.03 & 1 & 0.03 & 3 & 0.09 & 2 & 0.06 & 8 & 0.25 \\
\hline Oregon Basin & 60 & 31 & 2 & 0.03 & 5 & 0.08 & 6 & 0.10 & 8 & 0.13 & 8 & 0.13 & 2 & 0.03 \\
\hline Polecat Bench & 62 & 48 & 6 & 0.10 & 4 & 0.06 & 12 & 0.19 & 13 & 0.21 & 11 & 0.18 & 2 & 0.03 \\
\hline Total & 204 & 119 & 16 & & 13 & & 21 & & 33 & & 24 & & 12 & \\
\hline
\end{tabular}

${ }^{a}$ Major Basin: 6 badger, 1 gopher snake, 1 pronghorn; Oregon Basin: 1 fox, 1 skunk; Polecat Bench: 2 badger.

0.214 coyotes $/ \mathrm{km}^{2}$ (E. M. Gese and P. A. Terletzky, unpublished report). By suppressing coyote control, we expected coyote density at Oregon Basin to increase to $0.392 / \mathrm{km}^{2}$ (E. M. Gese and P. A. Terletzky, unpublished report), reflecting disproportionately more nests lost to coyotes. Contrary to our expectations, we found Oregon Basin (no removal) had one of the highest rates of nest survival in this study $(0.45 \pm 0.03)$ with proportion of nests lost to coyotes fewer than Fifteen Mile and Polecat Bench. No control of other mesopredators at Oregon Basin also may explain why we saw a diverse suite of nest predators there, including 6 nests lost to ravens and the only reported nests lost to red fox and striped skunk. However, estimates of predator abundance and prey base by year were lacking. This information would greatly improve the ability to relate variation in sage-grouse nest survival to community-level predator-prey dynamics.

Our use of a generalized linear modeling approach to estimate nest survival (Rotella et al. 2004) is thought to be a better estimator than traditional approaches such as the Mayfield method (Mayfield 1961), which may overestimate this vital rate (Dinsmore et al. 2002). Published nest survival estimates from a meta-analysis of 50 studies across the sagegrouse range (1938-2011) were between 0.38 and 0.53 (Taylor et al. 2012), although more recent studies reported estimates as low as 0.22 in northwestern Nevada (Lockyer et al. 2013) and from 0.25 to 0.43 in south-central Wyoming (Hansen et al. 2016). Nevertheless, we chose to use all available estimates of nest survival (Taylor et al. 2012) for general comparative purposes. Presuming previous estimates of nest survival reported across the sage-grouse range could be overestimated, our estimates $(0.20-0.56)$ still represent the full range of published rates. With the exception of 1 site, our nest survival rates were consistent with sustainable populations, assuming other vital rates are acceptable.

Our nest survival rate at Polecat Bench $(0.20)$ was below the cautionary threshold set by Connelly et al. (2000), in which measures to improve habitat or enforce short-term predator reduction may be necessary. The main differences that we observed between Polecat Bench and the other sites were that Polecat Bench had the lowest coyote removal $/ \mathrm{km}^{2}$ of the 4 managed sites, had the most mesopredators removed relative to other sites, had the greatest proportions of nests lost to coyotes and ravens relative to other sites, and had the greatest number of observed raven nests on infrastructure relative to other sites. Coyote removal was generally consistent over time, suggesting the number of coyotes removed annually reduced conflict at that site. The larger, more diverse guild of mesopredators causing conflict with livestock production on Polecat Bench suggests there may be subtle differences in the farming-agricultural landscape that warrant further investigation. Nevertheless, we observed very little nest loss to mesocarnivores over a 4-year period. The effects of ravens on nest survival of birds are well documented, including sage-grouse (Coates et al. 2008, Coates and Delehanty 2010) and sharp-tailed grouse (Tympanuchus phasianellus; Manzer and Hannon 2005). Although we have no data to contrast relative abundance of ravens between sites, we feel that additional research is warranted to proactively address potential increases in raven population size and subsequent sage-grouse nest loss in Bighorn Basin.

Continued growth and range expansion of raven populations into sagebrush ecosystems will likely result in greater instances of sage-grouse nest failure to ravens (Bui et al. 2010, Coates and Delehanty 2010, Dinkins et al. 2016). Raven populations have increased range-wide and locally since 1966 (Sauer et al. 2014). In Wyoming, raven populations increased $4.96 \%$ per year between 2003 and 2013 (Sauer et al. 2014). Active raven nesting density in nearby northwestern Wyoming was observed to be between 0.38 and 0.73 occupied nests $/ \mathrm{km}^{2}$ with a mean distance of $1.58 \mathrm{~km}$ between occupied nests in nesting habitat (Dunk et al. 1994). Currently unoccupied anthropogenic nesting structures in Bighorn Basin provide the means for continued range expansion and creation of habitat sinks for grouse (Aldridge and Boyce 2007). Although sagegrouse use a strategy to hide nests from visual predators (Conover et al. 2010), high raven density (including breeding pairs) combined with anthropogenic structures for nesting and perching, may lead to unusually high rates of sage-grouse nest loss. Dinkins et al. $(2012,2014,2016)$ suggested that even the best quality sagebrush communities may be rendered functionally unavailable to sage-grouse when raven densities are high.

Mezquida et al. (2006) argued that coyote removal, primarily by USDA/APHIS/WS, could result in 
mesopredator release and lead to increased depredation of sage-grouse nests by other species such as badger, raven, red fox; however, their essay was based on theoretical constructs with no supporting data. In southwestern Wyoming, Dinkins et al. (2016) associated lower sage-grouse nest survival with a mesopredator release caused by an interaction of lethal coyote control for livestock protection and greater precipitation. Although their assertion of a mesopredator release is plausible, it is not supported by documented changes in predator abundance (apex and mesopredators) or range expansion of mesopredators, nor did they document cause-specific nest failure (Dinkins et al. 2016). An alternate theory is that coyotes that were removed for livestock protection were rapidly replaced (Knowlton 1972, Windberg and Knowlton 1988, Conner et al. 2008) and may not have depredated nests.

The mesopredator release hypothesis states that reduction or elimination of top carnivores results in increases of mesopredators and declines in prey species (Estes 1996, Terborgh et al. 2001, Gehrt and Prange 2006). Identifying a mesopredator release is difficult and requires simultaneous evaluation of changes in abundance of predator and prey in time and space. We lack data on abundance of predator and prey associated with lethal removal; therefore, we cannot state with certainty that mesopredators did or did not benefit from lethal coyote removal in this study. However, we know that coyote removal per $\mathrm{km}^{2}$ was consistent among sites over time, and that coyote densities in Wyoming are greatest in sagebrush communities where coyotes are removed to protect agriculture. If a mesopredator release did occur as a result of predator removal during this study, it was not evident in sage-grouse nest loss among our sites. For example, our site with no predator removal (Oregon Basin) had the second highest nest loss by ravens and was the only site with nest loss to fox and skunk. This would be an expected outcome of a shift in trophic levels, yet no coyotes were removed there. In comparison, Polecat Bench had the greatest nest loss by ravens yet the least coyotes removed per $\mathrm{km}^{2}$. This also is inconsistent with the predator release hypothesis.

Assessments of nest loss based on physical sign can be difficult because there can be intraspecific variation in sign left at the site (Lariviere and Messier 1997, Lariviere 1999, Williams and Wood 2002) and predators of different species or classes can leave similar evidence (Lariviere 1999, Coates et al. 2008). Taken in combination, these factors make identification of the cause of nest loss by sign interpretation highly prone to error (Williams and Wood 2002, Coates et al. 2008, Lockyer et al. 2013). Conover and Roberts (2017) warned that efforts to preserve sage-grouse populations rely on a better understanding of the interactions between sagegrouse and their predators. They reported few studies where nest fate was confirmed through direct observation or remote sensing (e.g., camera or video; Conover and Roberts 2017). Our efforts to determine cause-specific nest fate were supported by the use of camera traps. This technology provides a tremendous advantage over interpreting sign after nest loss, yet it is not without error. Approximately $12 \%$ of the nests we located were classified as failures to an unidentified source. Lack of photographic evidence included human error, camera error, weather or animal effects (i.e., camera knocked over), and loss of nest early in incubation before a camera could be set up. Physical evidence assessed at each nest site by experienced observers was often confirmed by camera observations; however, images sometimes overrode physical assessments. For example, preliminary inspection of sign at a failed nest site in Oregon Basin indicated nest depredation by coyote was the likely cause of nest failure. Photographic evidence revealed the source of nest loss was due to female mortality by a pair of golden eagles (Aquila chrysaetos). Approximately 24 minutes after the female was killed on the nest, coyotes were recorded scavenging the nest site.

Use of field assessments alone will continue to produce spurious results regarding nest fate. Additionally, studies that categorize nest fate by hatch or fail, lack the detail necessary to make management decisions regarding predators. This includes prescribing the preferred vegetation dimensions and composition to deter visual and olfactory predators. We support the continued use of camera traps or video in identifying nest predators until variation in field assessments is reduced or improved technology is identified.

\section{MANAGEMENT IMPLICATIONS}

Our data support that continued coyote management to reduce livestock and big game depredation in Bighorn Basin is not likely to be detrimental to sage-grouse nest survival. Increased and sustained levels of coyote removal do not seem necessary at this time to protect sage-grouse; however, the potential effects of coyote removal remain unknown for adult female and chick survival. Given our direct observations of ravens perching and nesting on anthropogenic structures on Polecat Bench, we suggest that further research is necessary to evaluate the effects of raven management on sage-grouse nest survival. Options range from non-lethal techniques to prevent raven occupancy (primarily nesting) to selective lethal removal of ravens. It is unclear if sage-grouse nest loss due to raven activity is compensatory or additive; thus, it is important to monitor vital rates of sage-grouse with the addition of raven control measures.

\section{ACKNOWLEDGMENTS}

This study was conducted by the USDA/APHIS/WS/ National Wildlife Research Center in coordination with the Meeteetse Conservation District (MCD) of Wyoming. This project would have been impossible without the cooperation of private landowners throughout the Bighorn Basin that allowed field and research staff access to conduct monitoring activities. The data collection was carried out by Oregon State University, Utah State University, MCD, and the professional staff of the USDA/APHIS/WS Northwest Wyoming District. Many cooperators also contributed financially or provided logistical support for the study and included Utah State University, the Bighorn Basin Conservation Districts, Bighorn Basin Predator Management Districts, WYO-BEN, BreitBurn Operating LP, Marathon Oil Company, Fidelity Oil Company, Wyoming Animal 
Damage Management Board, V Ranch, Belden Ranch, Park County Farm Bureau, Wyoming Game and Fish Department, U.S. Bureau of Land Management, and the Shoshone National Forest. The synthesis of the 4 years of data included in this manuscript was made possible by a grant from the Wyoming Wildlife and Natural Resources Trust.

\section{LITERATURE CITED}

Akaike, H. 1973. Information theory and an extension of the maximum likelihood principle. Page 267-281 in B. N. Petran and F. Csaki, editors. International Symposium on Information Theory. Second edition. Akademiai Kiado, Budapest, Hungary.

Aldridge, C. L., and M. S. Boyce. 2007. Linking occurrence and fitness to persistence: habitat-based approach for endangered greater sage-grouse. Ecological Applications 17:508-526.

Anderson, D. R., K. P. Burnham, and W. L. Thompson. 2000. Null hypothesis testing: problems, prevalence, and an alternative. Journal of Wildlife Management 64:912-923.

Blaisdell, J. P., and R. C. Holmgren. 1984. Managing intermountain rangelands: salt desert shrub ranges. General technical Report INT163. U.S. Department of Agriculture Forest Service, Intermountain Forest and Range Experiment station, Ogden, Utah, USA.

Braun, C. E. 1998. Sage grouse declines in western North America: what are the problems? Proceedings of the Western Association of State Fish and Wildlife Agencies 78:139-156.

Bui, T. D., J. M. Marzluff, and B. Bedrosian. 2010. Common raven activity in relation to land use in western Wyoming: implications for greater sagegrouse reproductive success. Condor 112:65-78.

Burnham, K. P., and D. R. Anderson. 1998. Model selection and multimodel inference: a practical information-theoretic approach. Springer. New York, New York, USA.

Chapman, S. S., S. A. Bryce, J. M. Omernick, D. G. Despain, J. ZumBerge, and M. Conrad. 2004. Ecoregions of Wyoming (color poster map, descriptive text, summary tables, and photographs). U.S. Geological Survey, Reston, Virginia, USA.

Coates, P. S., J. W. Connelly, and D. J. Delehanty. 2008. Predators of greater sage-grouse nests identified by video monitoring. Journal of Field Ornithology 79:421-428.

Coates, P. S., and D. J. Delehanty. 2010. Nest predation of greater sagegrouse in relation to microhabitat factors and predators. Journal of Wildlife Management 74:240-248.

Connelly, J. W., and C. E. Braun. 1997. Long-term changes in sage grouse Centrocercus urophasianus populations in western North America. Wildlife Biology 3:229-234.

Connelly, J. W., K. P. Reese, and M. A. Schroeder. 2003. Monitoring of greater sage-grouse habitats and populations. Station Bulletin 80 . University of Idaho, College of Natural Resources Experiment Station, Moscow, Idaho, USA.

Connelly, J. W., M. A. Schroeder, A. R. Sands, and C. E. Braun. 2000. Guidelines to manage sage-grouse populations and their habitats. Wildlife Society Bulletin 28:967-985.

Conner, M. M., M. R. Ebinger, and F. F. Knowlton. 2008. Evaluating coyote management strategies using a spatially explicit, individual-based, socially structured population model. Ecological Modelling 219:234-247.

Conover, M. R., J. S. Borgo, R. E. Dritz, J. B. Dinkins, and D. K. Dahlgren. 2010. Greater sage-grouse select nest sites to avoid visual but not olfactory predators. Condor 112:331-336.

Conover, M. R., and A. J. Roberts. 2017. Predators, predator removal, and sage-grouse: a review. Journal of Wildlife Management 81:7-15.

Cox, W. A., M. S. Pruett, T. J. Benson, S. J. Chiavacci, and F. R. Thompson III. 2012. Development of camera technology for monitoring nests. Pages 185-210 in C. A. Ribic, F. R. Thompson III, and P. J. Pietz, editors. Video surveillance of nesting birds. Studies in Avian Biology 43. University of California Press, Berkeley, USA.

Crawford, J. A., and R. S. Lutz. 1985. Sage grouse population trends in Oregon, 1941-1983. Murrelet 66:69-74.

Crawford, J. A, R. A. Olsen, N. E. West, J. C. Mosley, M. A. Schroeder, T. D. Whitson, R. F. Miller, M. A. Gregg, and C. S. Boyd. 2004. Ecology and management of sage-grouse and sage-grouse habitat. Journal of Range Management 57:2-19.
Crunden, C. W. 1963. Age and sex of sage grouse from wings. Journal of Wildlife Management 27:846-849.

DeLong, A. K., J. A. Crawford, and D. C. DeLong. 1995. Relationships between vegetational structure and predation of artificial sage grouse nests. Journal of Wildlife Management 59:88-92.

Dinkins, J. B., M. R. Conover, C. P. Kirol, and J. L. Beck. 2012. Greater sage-grouse (Centrocercus urophasianus) select nest sites and brood sites away from avian predators. Auk 29:600-610.

Dinkins, J. B., M. R. Conover, C. P. Kirol, and J. L. Beck, and S. N. Frey. 2014. Greater sage-grouse (Centrocercus urophasianus) select habitat based on avian predators, landscape composition, and anthropogenic features. Condor 116:629-642.

Dinkins, J. B., M. R. Conover, C. P. Kirol, J. L. Beck, and S. N. Frey. 2016. Effects of common raven and coyote removal and temporal variation in climate on greater sage-grouse nesting success. Biological Conservation 202:50-58.

Dinsmore, S. J., G. C. White, and F. L. Knopf. 2002. Advanced techniques for modeling avian nest survival. Ecology 83:3476-3488.

Doherty, K. E., D. E. Naugle, H. Copeland, A. Pocewicz, and J. Kiesecker. 2011. Energy development and conservation tradeoffs: systematic planning for sage-grouse in their eastern range. Pages 505-516 in S. T. Knick and J. W. Connelly, editors. Greater sage-grouse: ecology and conservation of a landscape species and it habitats. Studies in Avian Biology 38. University of California Press, Berkeley, USA.

Dunk, J. R., S. L. Cain, M. E. Reid, and R. N. Smith. 1994. A high breeding density of common ravens in northwestern Wyoming. Northwestern Naturalist 75:70-73.

Estes, J. A. 1996. Predators and ecosystem management. Wildlife Society Bulletin 24:390-396.

Evans, K. L. 2004. The potential for interactions between predation and habitat change to cause population declines of farmland birds. Ibis 146:1-13.

Gehrt, S. D., and S. Prange. 2006. Interference competition between coyotes and raccoons: a test of the mesopredator release hypothesis. Behavioral Ecology 18:204-214.

Gregg, M. A., J. A. Crawford, M. S. Drut, and A. K. DeLong. 1994. Vegetational cover and predation of sage-grouse nests in Oregon. Journal of Wildlife Management 58:162-166.

Hagen, C. A. 2011. Predation on greater sage-grouse: facts, process, and effects. Pages 95-100 in S. T. Knock and J. W. Connelly, editors. Greater sage-grouse: ecology and conservation of a landscape species and it habitats. Studies in Avian Biology 38. University of California Press, Berkeley, USA.

Hansen, C. P., L. A. Schreiber, M. A. Rumble, J. J. Millspaugh, R. S. Gamo, J. W. Kehmeier, and N. Wojcik. 2016. Microsite selection and survival of greater sage-grouse nests in south-central Wyoming. Journal of Wildlife Management 80:862-876.

Hess, J. E., and J. L. Beck. 2012. Burning and mowing Wyoming big sagebrush: do treated sites meet minimum guidelines for greater sagegrouse breeding habitats? Wildlife Society Bulletin 36:85-93.

Holloran, M. J., and S. H. Anderson. 2003. Direct identification of northern sage-grouse, Centrocercus urophasianus, nest predators using remote sensing cameras. Canadian Field Naturalist 117:308-310.

Holloran, M. J., B. J. Heath, A. G. Lyon, S. J. Slater, J. L. Kuipers, and S. H. Anderson. 2005. Greater sage-grouse nesting habitat selection and success in Wyoming. Journal of Wildlife Management 69:638-649.

Johnson, D. H. 1979. Estimating nest success: the Mayfield method and an alternative. Auk 96:651-661.

Kirol, C. P., A. L. Sutphin, L. Bond, M. R. Fuller, and T. L. Maechtle. 2015. Mitigation effectiveness for improving nesting success of greater sage-grouse influenced by energy development. Wildlife Biology 21:98-109.

Knick, S. T., D. S. Dobkin, J. T. Rotenberry, M. A. Schroeder, W. M. Vander Haegen, and C. van Riper III. 2003. Teetering on the edge or too late? Conservation and research issues for avifauna of sagebrush habitats. Condor 105:611-634.

Knight, D. H. 1994. Mountains and Plains: the ecology of Wyoming landscapes. Yale University Press, New Haven, Connecticut, USA.

Knowlton, F. F. 1972. Preliminary interpretations of coyote population mechanics with some management implications. Journal of Wildlife Management 369-382.

Lariviere, S. 1999. Reasons why predators cannot be inferred from nest remains. Condor 101:718-721. 
Lariviere, S., and F. Messier. 1997. Characteristics of waterfowl nest depredation by striped skunk (Mephitis mephitis): can predators be identified from nest remains? American Midland Naturalist 137:393-396.

Leopold, A. 1933. Predator control. Pages 230-252 in Game management. 1946, Reprint. Charles Scribner's Sons, New York, New York and University of Wisconsin Press, Madison, USA.

Lockyer, Z. B., P. S. Coates, M. L. Casazza, S. Espinosa, and D. J. Delehanty. 2013. Greater sage-grouse nest predators in the Virginia Mountains of northwestern Nevada. Journal of Fish and Wildlife Management 4:242-254.

Manzer, D. L., and S. J. Hannon. 2005. Relating grouse nest success and corvid density to habitat: a multi-scale approach. Journal of Wildlife Management 69:110-123.

Mayfield, H. F. 1961. Nesting success calculated from exposure. Wilson Bulletin 73:255-261.

Mezquida, E. T., S. J. Slater, and C. W. Benkman. 2006. Sage-grouse and indirect interactions: potential implications of coyote control on sagegrouse populations. Condor 108:747-759.

Miller, R. F., S. T. Knick, D. A. Pyke, C. W. Meinke, S. E. Hanser, M. J. Wisdom, and A. L. Hild. 2011. Characteristics of sagebrush habitats and limitations to long-term conservation. Studies in Avian Biology 38:145-184.

Moynahan, B. J., M. S. Lindberg, J. J. Rotella, and J. W. Thomas. 2007. Factors affecting nest survival of greater sage-grouse in northcentral Montana. Journal of Wildlife Management 71:1773-1783.

Noss, R. F., E. T. LaRoe III, and J. M. Scott. 1995. Endangered ecosystems. A preliminary assessment of loss and degradation. U.S. Department of the Interior National Biological Service Biological Report 28, Washington, D.C., USA.

Omernick, J., and G. Griffith. 2012. Ecoregions of Wyoming. Office of Research and Development's Environmental Monitoring and Assessment Program. U.S. Environmental Protection Agency, Washington, D.C., USA. http://www.eoearth.org/view/article/152236. Accessed 23 Mar 2016.

Orning, E. K. 2014. Effect of predator removal on greater sage-grouse (Centrocercus urophasianus) ecology in the Bighorn Basin Conservation Area of Wyoming. Thesis, Utah State University, Logan, USA.

Powell, L. A. 2007. Approximating variance of demographic parameters using the delta method: a reference for avian biologists. Condor 109:949-954.

R Core Team. 2013. R: a language and environment for statistical computing. R Foundation for Statistical Computing, Vienna, Austria.

Reynolds, J. C., and S. C. Tapper. 1996. Control of mammalian predators in game management and conservation. Mammal Review 26:127-155.

Richardson, T. W., T. Gardali, and S. H. Jenkins. 2009. Review and metaanalysis of camera effects on avian nest success. Journal of Wildlife Management 73:287-293.

Rotella, J. J., S. J. Dinsmore, and T. L. Shaffer. 2004. Modeling nest-survival data: a comparison of recently developed methods that can be implemented in MARK and SAS. Animal Biodiversity and Conservation 27:187-205.

Samuel, M. D., and M. R. Fuller. 1994. Wildlife radiotelemetry. Pages 370-418 in T. A. Bookhout, editor. Research and management techniques for wildlife and habitats. Fifth edition. The Wildlife Society, Bethesda, Maryland, USA.

Sauer, J. R., J. E. Hines, J. E. Fallon, K. L. Pardieck, D. J. Ziolkowski Jr., and W. A. Link. 2014. The North American breeding bird survey, results and analysis 1966-2013. Version 01.30.2015. USGS Patuxent Wildlife Research Center, Laurel, Maryland, USA.

Schemnitz, S. D. 1994. Capturing and handling wild animals. Pages 106-124 in T. A. Bookhout, editor. Research and management techniques for wildlife and habitats. Fifth edition. The Wildlife Society, Bethesda, Maryland, USA.
Schroeder, M. A., C. L. Aldridge, A. D. Apa, J. R. Bohne, C. E. Braun, S. D. Bunnell, J. W. Connelly, P. A. Deibert, S. C. Gardner, M. A. Hilliard, G. D. Kobriger, S. M. McAdam, C. W. McCarthy, J. J. McCarthy, D. L. Mitchell, E. V. Rickerson, and S. J. Stiver. 2004. Distribution of sage-grouse in North America. Condor 106:363-376.

Schroeder, M. A., and R. K. Baydack. 2001. Predation and the management of prairie grouse. Wildlife Society Bulletin 29:24-32.

Schroeder, M. A., J. R. Young, and C. E. Braun. 1999. Sage grouse: Centrocercus urophasianus. Number 425 in A. Poole and F. Gill, editors. Birds of North America. The Birds of North America, Inc., Philadelphia, Pennsylvania, USA.

Seber, G. A. F. 1982. The estimation of animal abundance and related parameters. Second edition. Macmillan Book, New York, New York, USA.

Taylor, R. L., B. L. Walker, D. E. Naugle, and L. S. Mills. 2012. Managing multiple vital rates to maximize greater sage-grouse population growth. Journal of Wildlife Management 76:336-347.

Terborgh J., L. Lopez, P. Nuñez, M. Rao, G. Shahabuddin, G. Orihuela, M. Riveros, R. Ascanio, G. H. Adler, T. D. Lambert, and L. Balbas. 2001. Ecological meltdown in predator-free forest fragments. Science 294:1923-1926.

Treves, A., and L. Naughton-Treves. 2005. Evaluating lethal control in the management of human-wildlife conflict. Pages 86-106 in R. Woodroffe, S. Thrigood, and A. Rabinowitz, editors. People and wildlife: conflict or co-existence? Cambridge University Press, New York, New York, USA.

U.S. Fish and Wildlife Service. 2010. Endangered and threatened wildlife and plants; 12 -month findings for petitions to list the greater sage-grouse (Centrocercus urophasianus) as threatened or endangered. Federal Register 75:13909-14014.

U.S. Fish and Wildlife Service. 2015. Endangered and threatened wildlife and plants; 12 -month findings for petitions to list the greater sage-grouse (Centrocercus urophasianus) as threatened or endangered. Federal Register 80:59857-59942.

Wallestad, R., and D. Pyrah. 1974. Movement and nesting of sage grouse hens in central Montana. Journal of Wildlife Management 38:630-633.

Webb, S. L., C. V. Olsen, M. R. Dzialak, S. M. Harju, J. B. Winstead, and D. Lockman. 2012. Landscape features and weather influence nest survival of a ground-nesting bird of conservation concern, the greater sage-grouse, in human-altered environments. Ecological Processes 1:4. DOI: 10.1186/ 2192-1709-1-4

Western Regional Climate Center. 2016. Cooperative climatological data summaries. Western Regional Climate Center, Reno, Nevada, USA. http://www.wrcc.dri.edu/summary. Accessed 24 Mar 2016.

White, G. C., and K. P. Burnham. 1999. Program MARK: survival estimation from populations Willis, M. J., G. P. Kiester Jr., D. A. Immel, D. M. Jones, R. M. Powell, and K. R. Durbin. 1993. Sage grouse in Oregon. Wildlife Research Report 15. Oregon Department of Fish and Wildlife, Portland, USA.

Williams, G. E., and P. B. Wood. 2002. Are traditional methods of determining nest predators and nest fates reliable? An experiment with wood thrushes (Hylocicbla mustelina) using miniature video cameras. Auk 119:1126-1132

Windberg, L. A., and F. F. Knowlton. 1988. Management implications of coyote spacing patterns in southern Texas. Journal of Wildlife Management 52:632-640.

Winward, A. H. 2004. Sagebrush of Colorado: taxonomy, distribution, ecology, and management. Colorado Division of Wildlife, Department of Natural Resources, Denver, USA.

Wyoming Game and Fish Department. 2010. Wyoming state wildlife action plan. Wyoming Game and Fish Department, Cheyenne, USA.

Associate Editor: Timothy Fulbright. 